(C) 2018, THE AUTHORS. Published by FASS Inc. and Elsevier Inc. on behalf of the American Dairy Science Association ${ }^{\circledR}$.

This is an open access article under the CC BY-NC-ND license (http://creativecommons.org/licenses/by-nc-nd/3.0/).

\title{
Effect of prophylactic oral calcium supplementation on postpartum mineral status and markers of energy balance of multiparous Jersey cows
}

\author{
A. Valldecabres, ${ }^{*}$ J. A. A. Pires, $\nmid$ and N. Silva-del-Río* $\ddagger^{1}$ \\ *Veterinary Medicine Teaching and Research Center, 18830 Road 112, Tulare, CA 93274 \\ †INRA, Université Clermont Auvergne, VetAgro Sup, UMR Herbivores, F-63122 Saint-Genès-Champanelle, France \\ ‡Department of Population Health and Reproduction, School of Veterinary Medicine, University of California, Davis 95616
}

\begin{abstract}
The effects of prophylactic oral Ca supplementation on blood mineral status and markers of energy balance were evaluated on 205 multiparous Jersey cows at a commercial dairy. Postpartum, cows were systematically assigned to control $(\mathrm{n}=105)$ or oral Ca supplementation (CaOS; 50 to $60 \mathrm{~g}$ of $\mathrm{Ca}$ as boluses; $\mathrm{n}=100$ ) at 0 and $1 \mathrm{~d}$ in milk (DIM). Blood samples for analysis of serum minerals ( $\mathrm{Ca}, \mathrm{P}, \mathrm{Mg}, \mathrm{K}, \mathrm{Na}, \mathrm{Fe}, \mathrm{Zn}$, and $\mathrm{Cu}$ ) were collected before and $1 \mathrm{~h}$ after treatment at 0 and 1 DIM, and at 2 DIM. Urine $\mathrm{pH}$ was measured immediately before and $1 \mathrm{~h}$ after treatment administration $(\mathrm{n}=96)$. A subset of 74 cows was evaluated for plasma glucose and fatty acid concentrations at 0,1 , and 2 DIM. Cows were classified according to their initial calcemic status (Ca status) as normocalcemic (NC; serum $\mathrm{Ca}>2.12 \mathrm{mmol} / \mathrm{L})$ or subclinically hypocalcemic $(\mathrm{SCH}$; serum $\mathrm{Ca} \leq 2.12 \mathrm{mmol} / \mathrm{L})$. Average serum Ca concentration was higher in CaOS than control cows (2.12 vs. $2.06 \mathrm{mmol} / \mathrm{L})$; this treatment effect was higher for $\mathrm{SCH}$ [CaOS (2.03 mmol/L); control $(1.89 \mathrm{mmol} / \mathrm{L})]$ than NC cows [CaOS (2.22 mmol/L); control $(2.22 \mathrm{mmol} / \mathrm{L})]$. The incidence of subclinical hypocalcemia was lower for CaOS than control cows (53 vs. 65\%); however, at 2 DIM the prevalence of subclinical hypocalcemia tended to be higher for CaOS cows, mostly because it was higher for CaOS-NC than control-NC cows $(70$ vs. 25\%). Urine $\mathrm{pH}$ was lower for CaOS than control cows (6.10 vs. 7.04). Lower serum $\mathrm{Mg}$ concentration was detected for CaOS-SCH $(1.06 \mathrm{mmol} / \mathrm{L})$ than for control-SCH $(1.10 \mathrm{mmol} / \mathrm{L})$ cows. Cows in the CaOS group had higher serum K (4.68 vs. $4.53 \mathrm{mmol} / \mathrm{L}$ ), lower plasma glucose (2.97 vs. $3.10 \mathrm{mmol} / \mathrm{L})$, and at 2 DIM higher plasma fatty acid concentrations ( 0.43 vs. 0.35 $\mathrm{mmol} / \mathrm{L}$ ) than control cows. Our results showed that postpartum serum Ca concentration increases with oral
\end{abstract}

Received March 22, 2017.

Accepted January 9, 2018.

${ }^{1}$ Corresponding author: nsilvadelrio@ucdavis.edu
Ca supplementation, but calcemic status influenced treatment response. Future studies should evaluate the long-term implications on production and reproduction of oral Ca supplementation in Jersey cows.

Key words: oral calcium supplementation, subclinical hypocalcemia, dairy cow

\section{INTRODUCTION}

The abrupt increase in Ca requirements of periparturient dairy cows challenges their homeorhetic mechanisms to maintain optimal blood Ca concentration to support biological functions. For instance, Ca concentration in colostrum averages $4.7 \mathrm{~g} / \mathrm{kg}$ (Kehoe et al., 2007); the amount of Ca secreted in $5 \mathrm{~kg}$ of colostrum is 8 times the Ca present in the plasma pool of a $600-\mathrm{kg}$ cow (Goff, 2004). Subclinical hypocalcemia is associated with impaired neutrophil function, increased risk of disease (subclinical ketosis, displaced abomasum, metritis, and subclinical endometritis), reduced DMI and milk yield, and decreased odds of pregnancy at first AI (Chapinal et al., 2011, 2012; Martinez et al., 2012, 2014; Ribeiro et al., 2013). Evidence indicates that subclinical hypocalcemia can affect the metabolic status of cows, decrease insulin concentration, and increase fatty acid mobilization, lipid accumulation in liver, and blood glucose concentration (Reinhardt et al., 2011; Chamberlin et al., 2013; Martinez et al., 2014).

Nowadays, clinical hypocalcemia is relatively rare, but 41 to $54 \%$ of multiparous cows experience subclinical hypocalcemia ( $\mathbf{S C H}$; serum $\mathrm{Ca}<2.00 \mathrm{mmol} / \mathrm{L}$; Reinhardt et al., 2011). Recent studies reported that serum Ca concentration below 2.10 to $2.20 \mathrm{mmol} / \mathrm{L}$ was negatively associated with production, reproduction, and health outcomes. These studies suggest that the threshold for SCH should be higher than the traditional $2.00 \mathrm{mmol} / \mathrm{L}$ (Chapinal et al., 2011, 2012; Martinez et al., 2012, 2014). The identification of cows with SCH remains a challenge. The absence of clinical signs and the lack of cow-side diagnostic tools leave prophylactic strategies as the only treatment alternative. Feeding anionic salts to close-up cows is a common strategy 
used in over $50 \%$ of large ( $>500$ cows) US dairy herds (USDA NAMHS, 2014) and has successfully reduced the incidence of clinical hypocalcemia (Moore et al., 2000; Charbonneau et al., 2006). However, SCH still remains a problem in dairies feeding anionic salts to close-up cows. In a recent study, the prevalence of $\mathrm{SCH}$ within $24 \mathrm{~h}$ postpartum (serum $\mathrm{Ca}<2.12 \mathrm{mmol} / \mathrm{L}$ ) in 11 commercial dairies feeding close-up negative dietary cation-anion difference rations was $59 \%$ for multiparous cows (Brady, 2013).

Additional management strategies to prevent detrimental effects of SCH are peripartum intravenous, subcutaneous, or oral Ca supplementation. After supplementation, Ca hemodynamics vary with route of administration. Blanc et al. (2014) showed that prophylactic treatment of $\mathrm{SCH}$ with $10.7 \mathrm{~g}$ of intravenous $\mathrm{Ca}$ at parturition resulted in a transient hypercalcemia, followed by a hypocalcemic stage that lasted at least 24 h. In a recent study, the subcutaneous injection of 15.2 $\mathrm{g}$ of Ca was able to increase and maintain postpartum serum Ca concentration above $2.12 \mathrm{mmol} / \mathrm{L}$, and when administered in 2 doses ( $7.6 \mathrm{~g}$ of $\mathrm{Ca}$ at 0 and $1 \mathrm{DIM})$, decrease the risk of metritis and clinical and subclinical endometritis (Amanlou et al., 2016). Oral administration of 86 (0 and 1 DIM) and $43(2,3$, and 4 DIM) g of $\mathrm{Ca}$ as boluses had a positive effect on peripartum serum and blood ionized Ca concentration (Martinez et al., 2016). Nevertheless, Oetzel and Miller (2012) found that oral $\mathrm{Ca}$ supplementation (43 $\mathrm{g}$ of $\mathrm{Ca}$ as bolus) had no effect on blood ionized Ca concentration. The susceptibility to hypocalcemia varies by breed, with Jerseys having higher risk than Holsteins (Goff et al., 1995; Lean et al., 2006; Roche and Berry, 2006). However, most studies evaluating prophylactic strategies have been conducted on Holsteins. We hypothesized that oral supplementation with highly soluble forms of $\mathrm{Ca}$ would help not only to sustain serum Ca concentration in postpartum Jersey cows while homeorhetic mechanisms cope with the onset of lactation but also to improve postpartum mineral status and energy balance. Our objective was to evaluate the effect of prophylactic oral Ca supplementation (50 to $60 \mathrm{~g}$ of $\mathrm{Ca}$ as boluses) at 0 and 1 DIM on postpartum serum concentrations of $\mathrm{Ca}$ and other minerals as well as blood concentrations of markers of energy balance of multiparous Jersey cows fed a close-up ration with negative dietary cationanion difference.

\section{MATERIALS AND METHODS}

All procedures were approved by the University of California Davis Institutional Animal Care and Use Committee (\#18846).
Table 1. Ingredients and nutrient composition of close-up and fresh cow rations

\begin{tabular}{|c|c|c|}
\hline Item & Close-up & Fresh \\
\hline \multicolumn{3}{|l|}{ Ingredient $(\%$ of $\mathrm{DM})$} \\
\hline Almond hulls & - & 5.1 \\
\hline Aminoplus & - & 2.3 \\
\hline Canola & 17.4 & 12.0 \\
\hline Close-up mineral & 3.1 & - \\
\hline Corn silage & 38.0 & 11.0 \\
\hline Distillers dried grains & - & 4.8 \\
\hline Lactating cow mineral & - & 0.1 \\
\hline Limestone & 3.1 & - \\
\hline Mineral mix & - & 4.2 \\
\hline Rolled corn & 13.6 & 15.0 \\
\hline Rumen-protected fat & - & 0.2 \\
\hline Sorghum & - & 2.4 \\
\hline Soy hulls & 14.9 & 3.4 \\
\hline Straw & 9.3 & - \\
\hline Winter forage & - & 40.0 \\
\hline \multirow{2}{*}{\multicolumn{3}{|c|}{ Nutrient composition ${ }^{1}$ (DM basis) }} \\
\hline & & \\
\hline $\mathrm{CP}(\%)$ & 16.25 & 17.25 \\
\hline Crude fat $(\%)$ & 2.48 & 3.98 \\
\hline $\operatorname{ADF}(\%)$ & 26.30 & 20.10 \\
\hline NDF (\%) & 37.75 & 30.45 \\
\hline Lignin $(\%)$ & 4.17 & 4.66 \\
\hline Starch (\%) & 18.85 & 22.05 \\
\hline Ash $(\%)$ & 14.87 & 8.88 \\
\hline $\mathrm{Ca}(\%)$ & 2.86 & 1.19 \\
\hline $\mathrm{P}(\%)$ & 0.40 & 0.48 \\
\hline $\operatorname{Mg}(\%)$ & 0.43 & 0.36 \\
\hline $\mathrm{K}(\%)$ & 1.27 & 1.37 \\
\hline $\mathrm{S}(\%)$ & 0.47 & 0.34 \\
\hline $\mathrm{Na}(\%)$ & 0.13 & 0.29 \\
\hline $\mathrm{Cl}(\%)$ & 0.92 & 0.43 \\
\hline $\mathrm{DCAD}^{2}(\mathrm{mEq} / 100 \mathrm{~g})$ & -17.61 & 14.55 \\
\hline
\end{tabular}

${ }^{1}$ Wet chemistry analysis (Cumberland Valley Analytical Services; Hagerstown, MD).

${ }^{2}$ Dietary cation-anion difference calculations were performed according to the following equation: DCAD $(\mathrm{mEq} / 100 \mathrm{~g})=[(\mathrm{Na}+\mathrm{K})-(\mathrm{Cl}$ $+\mathrm{S})$ ].

\section{Study Herd Management}

The study was conducted on a commercial dry-lot Jersey herd in California from January to April 2016. The herd milked 2,789 cows twice a day, producing on average $23.8 \mathrm{~kg} / \mathrm{d}$ during the study period. During the last $3 \mathrm{wk}$ of gestation, dry cows were moved to a close-up pen and offered a corn silage-based TMR with anionic salts once a day (Table 1).

Close-up cows showing secondary signs of calving were moved to a prepartum pen. Once primary signs of calving were observed, cows were accommodated into individual calving pens bedded with straw. Calves were separated from dams immediately after parturition. Twice a day, fresh cows were moved from the maternity pen to a colostrum pen, where they stayed for $4 \mathrm{~d}$. From 4 to 14 DIM, cows were housed in a fresh cow pen, and later were moved to lactation pens. Cows housed in the colostrum and fresh cow pens were evaluated daily by 
farm personnel for signs of health disorders during the morning lock-up. All postpartum cows were offered the same TMR twice a day (Table 1 ).

\section{Experimental Design and Data Collection}

A sample-size calculation was conducted for our primary outcome, serum Ca concentration. A total of 107 cows per group were required to detect a $0.1 \mathrm{mmol} / \mathrm{L}$ difference at the $5 \%$ significance level with $80 \%$ power with a standard deviation of $0.26 \mathrm{mmol} / \mathrm{L}$ based on Blanc et al. (2014). Based on the standard deviation observed in our control group, this number of cows provided an $80 \%$ power to detect differences of 0.15 $\mathrm{mmol} / \mathrm{L}$ for $\mathrm{P}$ (SD $0.39 \mathrm{mmol} / \mathrm{L}$ ), $0.06 \mathrm{mmol} / \mathrm{L}$ for $\mathrm{Mg}$ (SD $0.14 \mathrm{mmol} / \mathrm{L}$ ), $0.15 \mathrm{mmol} / \mathrm{L}$ for $\mathrm{K}$ (SD 0.38 $\mathrm{mmol} / \mathrm{L}), 4.93 \mathrm{mmol} / \mathrm{L}$ for $\mathrm{Na}$ (SD $12.50 \mathrm{mmol} / \mathrm{L}$ ), $3.04 \mu \mathrm{mol} / \mathrm{L}$ for $\mathrm{Fe}(\mathrm{SD} 7.71 \mu \mathrm{mol} / \mathrm{L}), 1.05 \mu \mathrm{mol} / \mathrm{L}$ for $\mathrm{Cu}(\mathrm{SD} 2.66 \mu \mathrm{mol} / \mathrm{L}), 1.00 \mu \mathrm{mol} / \mathrm{L}$ for $\mathrm{Zn}(\mathrm{SD} 2.54$ $\mu \mathrm{mol} / \mathrm{L}$ ), and $0.2 \mathrm{mmol} / \mathrm{L}$ for BHB (SD $0.4 \mathrm{mmol} / \mathrm{L}$ ). The subset of cows sampled for plasma fatty acids and glucose had an $80 \%$ power to detect differences of 0.11 (SD $0.27 \mathrm{mmol} / \mathrm{L}$ ) and 0.58 (SD $1.47 \mathrm{mmol} / \mathrm{L}$ ) $\mathrm{mmol} / \mathrm{L}$, respectively. For urine $\mathrm{pH}$ evaluation, a total of 46 cows per group were deemed necessary to detect a urine $\mathrm{pH}$ difference of 0.4 units based on a standard deviation of 0.68 (Blanc et al., 2014).

A total of 218 multiparous cows were systematically assigned to 1 of the 2 treatment groups based on calving time: control (no oral Ca supplementation; $\mathrm{n}=108$ ) or oral Ca supplementation [CaOS; 2 doses of QuadriCalMINI (Bio-Vet Inc., Barneveld, WI) each containing 50 to $60 \mathrm{~g}$ of $\mathrm{Ca} ; \mathrm{n}=110$ ], with the first cow enrolled assigned to control group. Each oral Ca dose included 5 boluses as per label indication, with $\mathrm{CaCl}_{2}$ as the main Ca source and Ca propionate, Ca lactate, and $\mathrm{CaSO}_{4}$ as secondary sources. Researchers administered the first oral $\mathrm{Ca}$ dose in the maternity pen $2 \mathrm{~h} 50 \mathrm{~min}( \pm 2 \mathrm{~h}$ $01 \mathrm{~min}$ ) after calving (0 DIM), and the second dose at morning lock-up time during the fresh cow check, $18 \mathrm{~h}$
37 min ( \pm 6 h 8 min $)$ after the first dose (1 DIM). Farm employees were blinded to treatment assignment.

A single researcher scored cows for body condition using a 1 to 5 scale with 0.25 increments (Ferguson et al., 1994), and for locomotion using a 5-point scale (Sprecher et al., 1997). Feedbunk samples of close-up and fresh cow diets were collected once a month at feeding time. Feed samples were composited, dried, ground, and analyzed by wet chemistry (Cumberland Valley Analytical Services, Hagerstown, MD). Health records and pharmacological treatments of postpartum cows were obtained from the daily fresh cow check worksheets. Data from the previous lactation 305-d mature equivalent milk production, additional health events up to 30 DIM, culling, and herd removals were obtained from DairyComp305 herd records (Valley Ag Software, Tulare, CA).

\section{Sample Collection and Laboratory Analyses}

The study sampling timeline is shown in Figure 1. Blood samples for $\mathrm{Ca}, \mathrm{P}, \mathrm{Mg}, \mathrm{K}, \mathrm{Na}, \mathrm{Fe}, \mathrm{Zn}$, and $\mathrm{Cu}$ analyses were collected from the coccygeal vessels using an evacuated tube without anticoagulant (BD Vacutainer, Trace Element Serum, BD, Franklin Lakes, NJ). Relative to first and second treatment administration, samples were collected immediately before (0 DIM; 1 DIM) and $1 \mathrm{~h}$ after $(0$ DIM $+1 \mathrm{~h}$; 1 DIM $+1 \mathrm{~h})$; from 1 DIM to 1 DIM $+1 \mathrm{~h}$ cows remained in the headlocks with fresh feed available. In addition, the last 74 cows [control $(\mathrm{n}=38)$; $\mathrm{CaOS}(\mathrm{n}=36)]$ enrolled in the study were sampled during the fresh cow check lock-up at 2 DIM (45 h 30 min \pm 5 h 19 min after calving). Blood samples from those 74 cows were collected using an evacuated tube with $\mathrm{NaFl}$ as a glycolytic inhibitor (BD Vacutainer, BD, Franklin Lakes, NJ) for glucose and fatty acid analyses at 0,1 , and 2 DIM.

Immediately after drawing, blood samples were placed into a portable refrigerator set at $4^{\circ} \mathrm{C}$ and transported to the laboratory within $3 \mathrm{~h}$ after collec-
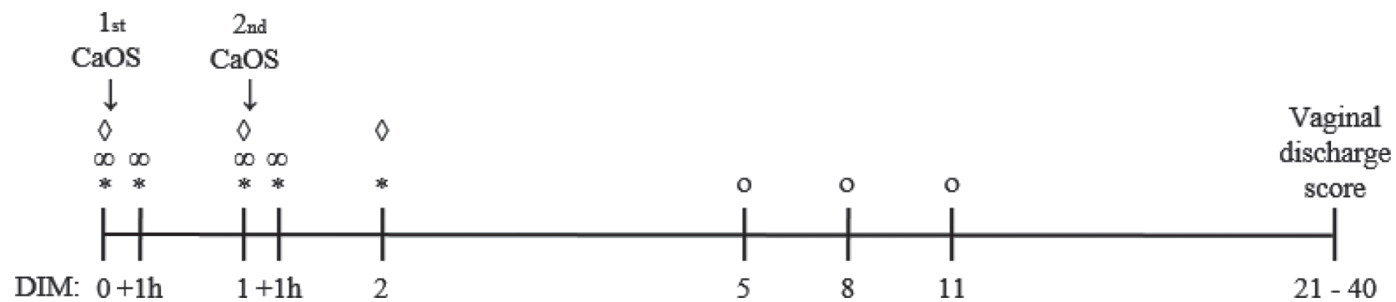

Figure 1. Study sampling timeline. CaOS $=$ treatment cows received 50 to $60 \mathrm{~g}$ of oral Ca at 0 and $1 \mathrm{DIM}$. *Blood samples for Ca, P, Mg, $\mathrm{K}, \mathrm{Na}, \mathrm{Fe}, \mathrm{Zn}$, and $\mathrm{Cu}$ were collected at 5 time points: $0,0+1 \mathrm{~h}, 1$, and $1+1 \mathrm{~h}$ DIM $(\mathrm{n}=205)$, and 2 DIM $(\mathrm{n}=74)$. $\infty$ Urine samples for $\mathrm{pH}$ measurement were collected at 4 time points: $0,0+1 \mathrm{~h}, 1$, and $1+1 \mathrm{~h}$ DIM $(\mathrm{n}=96)$. $\diamond$ Blood samples for fatty acids and glucose were collected at 3 time points: 0,1 , and 2 DIM $(n=74)$. OBlood samples for BHB were collected at 3 time points: 5, 8, and 11 DIM $(\mathrm{n}=205)$. Vaginal discharge score was performed once between 21 and 40 DIM $(\mathrm{n}=182)$. 
tion. The handling protocol for blood specimens was adequate for glucose analysis (Morris et al., 2002). Samples were centrifuged at $1,430 \times g$ for $15 \mathrm{~min}$ at $15^{\circ} \mathrm{C}$ and serum was stored at $-20^{\circ} \mathrm{C}$ until analysis. Frozen serum samples were shipped to the California Animal Health Food Safety laboratory (University of California, Davis) for $\mathrm{Ca}, \mathrm{P}, \mathrm{Mg}, \mathrm{K}, \mathrm{Na}, \mathrm{Fe}, \mathrm{Zn}$, and $\mathrm{Cu}$ analyses by Inductively Coupled Plasma-Optical Emission Spectrometry (Melton et al., 1990). Frozen plasma samples were shipped to Marshfield Labs (Marshfield, WI) and analyzed for glucose (hexokinase G-6-PDH method; Carroll et al., 1970) and fatty acid concentrations (Wako Chemical USA, Richmond, VA) using an automatic analyzer (AU5800, Beckman Coulter Inc., Brea, CA). Blood samples for BHB analysis were collected from the coccygeal vessels using a 25-gauge, $1.59-\mathrm{cm}$ needle and a $3-\mathrm{mL}$ syringe. Concentration of BHB in blood was determined cow-side using a handheld meter (Precision Xtra, Abbott, Alameda, CA; Iwersen et al., 2009) at 5, 8, and 11 DIM $(\mathrm{n}=205)$. The intra-assay and inter-assay coefficients of variation were 2.0 and $4.4 \%$ for $\mathrm{Ca}, 2.2$ and $3.7 \%$ for $\mathrm{P}, 2.3$ and $3.5 \%$ for $\mathrm{Mg}, 2.2$ and $2.2 \%$ for $\mathrm{K}, 2.2$ and $2.3 \%$ for $\mathrm{Na}$, 6 and $6.2 \%$ for Fe, 2.8 and $5.7 \%$ for $\mathrm{Zn}, 2$ and $5.2 \%$ for $\mathrm{Cu}, 0.4$ and $0.7 \%$ for glucose, and 0.7 and $2.8 \%$ for fatty acids, respectively.

Midstream urine samples were collected via manual stimulation for a subset of 96 cows $[\mathrm{CaOS}(\mathrm{n}=50)$; control $(\mathrm{n}=46)$ ], immediately before and $1 \mathrm{~h}$ after the first and second oral Ca dose administration. Urine $\mathrm{pH}$ was measured using a previously calibrated cow-side handheld meter (Horiba, Kyoto, Japan). Samples containing mucus, blood, or lochia were discarded.

\section{Definitions of Health Disorders}

Cows with serum Ca concentration $\leq 2.12 \mathrm{mmol} / \mathrm{L}$ $(8.5 \mathrm{mg} / \mathrm{dL})$ on at least one of the sampled days were considered to have SCH. This definition of $\mathrm{SCH}$ has been previously used by other authors (Amanlou et al., 2016: Martinez et al., 2016) based on the best cut-off point of $\mathrm{Ca}$ concentration in blood to predict either metritis $(\leq 2.14 \mathrm{mmol} / \mathrm{L}$; Martinez et al., 2012) or milk yield losses $(\leq 2.10 \mathrm{mg} / \mathrm{dL}$; Chapinal et al., 2012).

Cows with blood BHB concentration $\geq 1.2 \mathrm{mmol} / \mathrm{L}$ (LeBlanc et al., 2005) on at least one of the sampled days $(5,8$, or $11 \mathrm{DIM})$ were considered to have subclinical ketosis. During the daily fresh cow checks from 1 to 14 DIM, signs of health disorder and health events that lead to treatment were recorded on worksheets by farm personnel including fever (rectal temperature $\geq 39.5^{\circ} \mathrm{C}$ ), retained placenta (presence of fetal membranes at the time of first fresh cow check, between 8 and $32 \mathrm{~h}$ after calving), diarrhea, and metritis (presence of abnormal vaginal discharge).

Vaginal discharge was evaluated by researchers between 21 and 42 DIM (30 \pm 4 DIM; $\mathrm{n}=182)$, using Metricheck device (Metricheck, Simcro, Hamilton, New Zealand) as described by McDougall et al. (2007). The nature of discharge was evaluated following a 1 to 4 scoring system adapted from Williams et al. (2005), and classified as clear mucus (score 1), predominantly clear mucus with flecks of pus (score 2), mucopurulent mucus (score 3 ; approximately $50 \%$ pus and $50 \% \mathrm{mu}-$ cus), and purulent (score $4 ;>50 \%$ pus).

\section{Statistical Analyses}

Statistical analyses were performed using SAS (version 9.4, SAS Institute Inc., Cary, NC). Cows were classified according to their calcemic status before first treatment administration (Ca status) as normocalcemic [NC; $\mathrm{Ca}>2.12 \mathrm{mmol} / \mathrm{L}$; CaOS-NC ( $\mathrm{n}=34)$; control$\mathrm{NC}(\mathrm{n}=39)$ ] or subclinically hypocalcemic [SCH; Ca $\leq 2.12 \mathrm{mmol} / \mathrm{L}$; CaOS-SCH $(\mathrm{n}=66)$; control-SCH (n $=66)]$. The $t$-test, chi-squared, and exact Fisher tests were used to evaluate pretreatment differences between treatment and Ca status groups. Spearman correlations were used to explore relationships among numerical variables and potential covariates. Repeated measures data such as blood mineral and markers of energy balance concentrations and urine $\mathrm{pH}$ were analyzed by the MIXED procedure; models included the fixed effects of Ca status ( $\mathrm{NC}$ vs. $\mathrm{SCH}$ ), treatment (CaOS vs. control), time, 2- and 3-way interactions (i.e., Ca status $\times$ treatment, $\mathrm{Ca}$ status $\times$ time, treatment $\times$ time, and $\mathrm{Ca}$ status $\times$ treatment $\times$ time), and the random effect of cow. A correlation was observed between parity and Ca status at calving $(P<0.001)$; therefore, only Ca status was included in the repeated measures models. A tendency for a difference on serum Ca concentration by treatment group was observed at 0 DIM before the first oral $\mathrm{Ca}$ dose administration [CaOS (1.97 mmol/L); control $(2.05 \mathrm{mmol} / \mathrm{L})]$; in addition, differences on blood minerals and markers of energy balance concentrations were observed by Ca status (NC vs. SCH; Table 2). Therefore, a centered covariate by Ca status ( $\mathrm{NC}$ and $\mathrm{SCH}$ ) was calculated and kept in the model when significant for each blood mineral and metabolite analyzed. Centered covariates were calculated by subtracting the group mean ( $\mathrm{NC}$ or $\mathrm{SCH}$ ) to each observed value. This approach centers the LSMEANS estimates according to the mean Ca concentration for $\mathrm{NC}$ and SCH, respectively (Milliken and Johnson, 2001). Based on prior research (Oetzel and Miller, 2012), previous lactation 305-d mature equivalent milk yield and lo- 
comotion score at calving were tested as covariates for repeated measures of serum $\mathrm{Ca}$ concentration; these covariates were nonsignificant $(P=0.16$ and 0.22 , respectively) and therefore were removed from the model. Denominator degrees of freedom were calculated using the Kenward-Rogers adjustment. Variance-covariance structures [including spatial power, $\operatorname{AR}(1), \operatorname{ARH}(1)$, and CS] were evaluated; the one yielding the best fit according to Schwarz's Bayesian criterion was selected. Significant treatment by time interactions were explored by the Fisher's protected least significant difference using the SLICE and PDIFF options of the LSMEANS statement. Comparisons at each time point were mostly performed for control-NC versus CaOS-NC and for control-SCH versus CaOS-SCH. Logarithmic transformation of the data was used whenever needed to comply with the assumptions of normality and homoscedasticity of residuals. When transformation was needed, least squares means and standard errors of the mean were estimated from untransformed values, whereas $P$-values reflect statistical analysis of transformed data.
The GLIMMIX procedure was used to analyze the prevalence of $\mathrm{SCH}$ at each time point as repeated measures within the same animal, using a model that included the fixed effects described for the MIXED procedures [Ca status ( $\mathrm{NC}$ vs. $\mathrm{SCH})$, treatment (CaOS vs. control), time, Ca status $\times$ treatment, Ca status $\times$ time, treatment $\times$ time, and Ca status $\times$ treatment $\times$ time], and a spatial power variance-covariance structure. Treatment effects on the prevalence of $\mathrm{SCH}$, subclinical ketosis, and purulent vaginal discharge were evaluated with the chi-squared or exact Fisher test options of the FREQ procedure. The significance level was predefined as $P \leq 0.05$, and trends toward significance as $0.05<$ $P \leq 0.10$.

\section{RESULTS AND DISCUSSION}

The main objective of our study was to evaluate the effects of postpartum oral Ca supplementation for SCH prevention on blood mineral status and markers of energy balance of multiparous Jersey cows. The study was conducted on a commercial dairy farm that

Table 2. Baseline parameters of 205 multiparous Jersey cows at enrollment for control and treatment (CaOS), normocalcemic (NC), and subclinical hypocalcemia $(\mathrm{SCH})$ cows

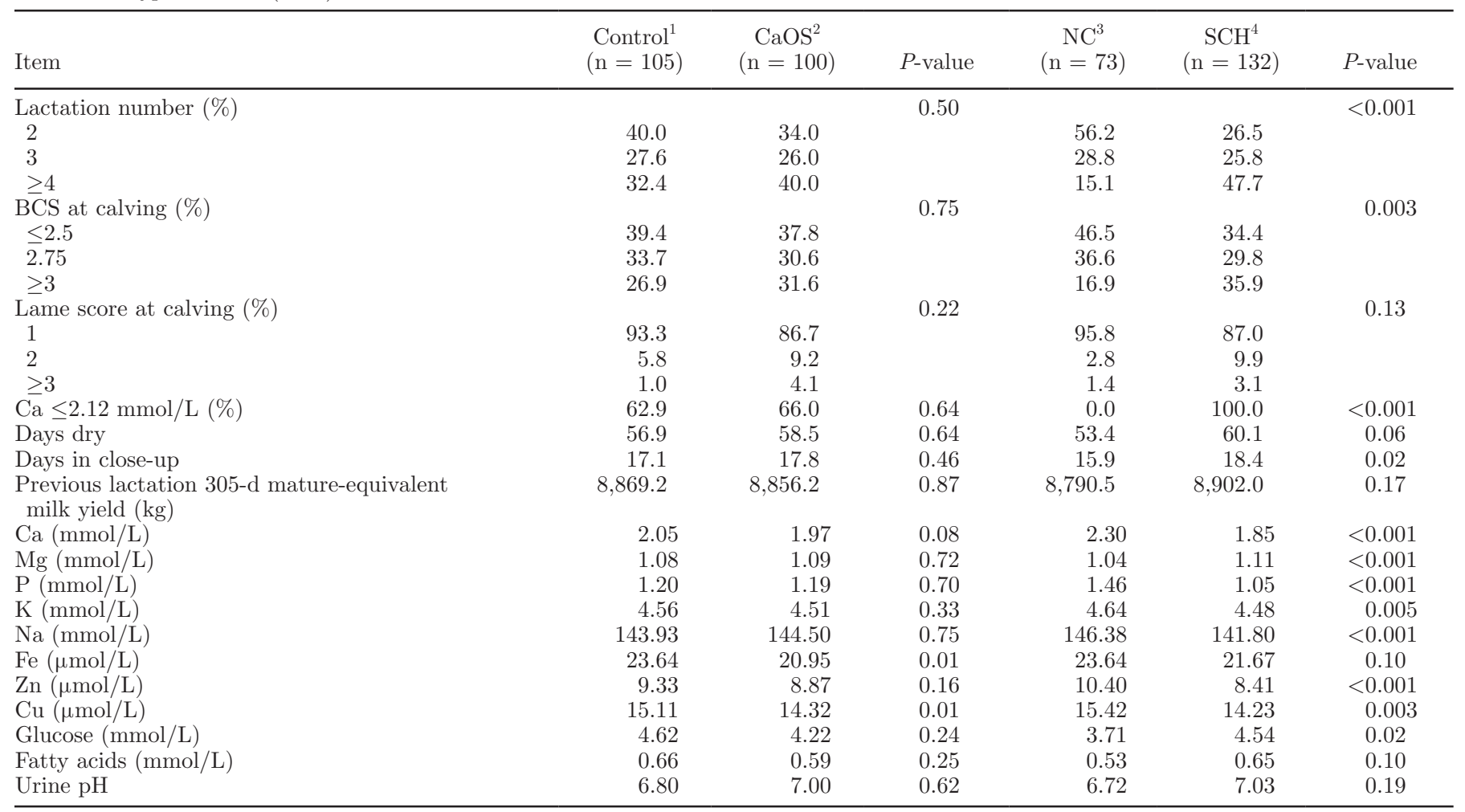

${ }^{1}$ Control: no Ca supplementation.

${ }^{2} \mathrm{CaOS}$ : cows received 50 to $60 \mathrm{~g}$ of oral $\mathrm{Ca}$ at 0 and $1 \mathrm{DIM}$.

${ }^{3} \mathrm{NC}$ : cows with serum Ca before treatment administration $>2.12 \mathrm{mmol} / \mathrm{L}$.

${ }^{4} \mathrm{SCH}$ : cows with serum $\mathrm{Ca}$ before treatment administration $\leq 2.12 \mathrm{mmol} / \mathrm{L}$. 
followed management practices representative of most dairy herds in the Central Valley of California. Initially 218 multiparous cows were enrolled, and 13 of those cows were removed from the study during the first 5 DIM. Cows removed from the study in control group received additional Ca therapy $(\mathrm{n}=2)$ or died $(\mathrm{n}=1)$, whereas cows in CaOS group missed an oral Ca dose (n $=5)$, received additional Ca therapy $(\mathrm{n}=2)$, or were sold $(\mathrm{n}=3)$. The final number of cows included in the study was 205 [control $(\mathrm{n}=105)$; CaOS $(\mathrm{n}=100)]$. To ensure study protocol compliance, researchers were the only individuals in charge of treatment administration, blood sample collection, vaginal discharge evaluation, and supervising herd records on a daily basis. At enrollment, control and CaOS groups did not differ based on number of lactations, BCS, locomotion score, dry and close-up period length, previous lactation 305-d mature equivalent milk yield, serum concentrations of minerals ( $\mathrm{Mg}, \mathrm{P}, \mathrm{K}, \mathrm{Na}, \mathrm{Zn}$ ), plasma concentrations of glucose and fatty acids, and urine $\mathrm{pH}$. However, CaOS cows had lower serum $\mathrm{Fe}$ and $\mathrm{Cu}$ concentrations and tended to have lower serum Ca concentration than control cows (Table 2).

The prevalence of $\mathrm{SCH}$ (serum $\mathrm{Ca} \leq 2.12 \mathrm{mmol} / \mathrm{L}$ ) before treatment initiation in the study dairy was 46 , 62 , and $85 \%$ for $2 \mathrm{nd}$, 3rd, and $\geq 4$ th lactation cows, respectively. To increase $\mathrm{Ca}$ levels in the close-up diet, the dairy nutritionist included limestone $\left(\mathrm{CaCO}_{3} ; 3.1 \%\right.$ of DM) as an inorganic Ca source, which resulted in a $\mathrm{Ca}$ concentration in the diet almost 3 -fold above the NRC recommendations. Zeolite, a mycotoxin binder with Ca binding properties, was included in the prepartum diet. Its inclusion rate was very low $(0.6 \%$ of $\mathrm{DM})$ and no interference with treatment was expected (Grabherr et al., 2009).

\section{Serum Calcium}

By Treatment and Time. Treatment, time, and treatment $\times$ time effects were observed on serum Ca concentration (Table 3). Serum Ca concentration was higher for $\mathrm{CaOS}$ than control cows (2.13 vs. 2.06 $\mathrm{mmol} / \mathrm{L} ; P=0.004)$. After treatment administration, a rapid increase occurred in serum Ca concentration for CaOS compared with control cows of 2.20 versus 2.03 $\mathrm{mmol} / \mathrm{L}$ at $0 \mathrm{DIM}+1 \mathrm{~h}$ and 2.16 versus $2.04 \mathrm{mmol} / \mathrm{L}$ at $1 \mathrm{DIM}+1 \mathrm{~h}(P<0.001)$. There was a minor increase of $0.04 \mathrm{mmol} / \mathrm{L}$ in serum Ca concentration in control cows from 1 DIM to $1 \mathrm{DIM}+1 \mathrm{~h}(P<0.001)$. The fast treatment response observed $1 \mathrm{~h}$ after oral Ca administration suggests that Ca sources included in the boluses were highly soluble; moreover, the immediate acidifying effect of these Ca sources favors the formation of
$\mathrm{Ca}$ ions readily available for absorption (Bronner and Pansu, 1999). This initial rise in serum Ca concentration was short lived, and at 1 DIM serum Ca concentration had declined by $0.15 \mathrm{mmol} / \mathrm{L}$ but still tended to be higher for CaOS compared with control cows $(2.05$ vs. $1.99 \mathrm{mmol} / \mathrm{L} ; P=0.07)$. Nonetheless, no treatment effect was detected at 2 DIM $(2.11$ vs. $2.17 \mathrm{mmol} / \mathrm{L} ; P$ $=0.32$ ). The decline in serum $\mathrm{Ca}$ concentration after treatment administration suggests that absorbed $\mathrm{Ca}$ was either taken up by the mammary gland or excreted by the kidneys. Prior studies evaluating the effects of oral Ca supplementation using a different commercial product containing $\mathrm{CaCl}_{2}$ and $\mathrm{CaSO}_{4}$ were also effective at increasing serum $\mathrm{Ca}$ levels within $1 \mathrm{~h}$ of treatment administration (Sampson et al., 2009; Martinez et al., 2016). However, when sampling times were scheduled at approximately $24 \mathrm{~h}$ after treatment, no effects were detected in blood Ca concentration (Melendez et al., 2002; Oetzel and Miller, 2012). Differences in Ca dose supplemented (50 vs. $43 \mathrm{~g}$ ), Ca sources, parity (only multiparous vs. all parities), prevalence of hypocalcemia, breed (Jersey vs. Holstein), or protocol compliance may explain the lack of treatment response observed in previous studies.

By Initial Ca Status. There were effects of Ca status and its interactions with treatment, time, and treatment $\times$ time on serum Ca concentration (Table 3; Figure 2). A remarkable effect was observed of Ca status on treatment response; CaOS-SCH cows had higher serum Ca concentration than control-SCH at 0 DIM + $1 \mathrm{~h}(2.07$ vs. $1.84 \mathrm{mmol} / \mathrm{L} ; P<0.001), 1 \mathrm{DIM}$ (1.91 vs. $1.82 \mathrm{mmol} / \mathrm{L} ; P=0.01)$, and $1 \mathrm{DIM}+1 \mathrm{~h}(2.06$ vs. $1.85 \mathrm{mmol} / \mathrm{L} ; P<0.001)$. However, $\mathrm{NC}$ cows had a marginal increase in serum Ca concentration after oral $\mathrm{Ca}$ administration with 2.32 versus $2.22 \mathrm{mmol} / \mathrm{L}$ for CaOS-NC and control-NC, respectively, at 0 DIM +1 $\mathrm{h}(P=0.03)$, but no differences at 1 DIM or 1 DIM + $1 \mathrm{~h}$. After oral administration of highly soluble sources of $\mathrm{Ca}$, a concentration gradient is expected between the lumen of the gastrointestinal tract and extracellular fluid that will favor passive absorption of $\mathrm{Ca}$ ions through the tight junctions of gastrointestinal epithelia cells (Bronner et al., 1986). Cows with subclinical hypocalcemia are more likely to have a greater gradient and decreased gastrointestinal motility (Martinez et al., 2014) that could potentially favor Ca absorption rate. Moreover, homeostatic mechanisms may prevent normocalcemic cows from experiencing an increase in serum $\mathrm{Ca}$ concentration above physiological limits. Based on a univariable linear regression, Miltenburg et al. (2016) reported a greater increase in serum Ca concentration after subcutaneous $\mathrm{Ca}$ supplementation among cows with lower initial serum Ca concentration. 


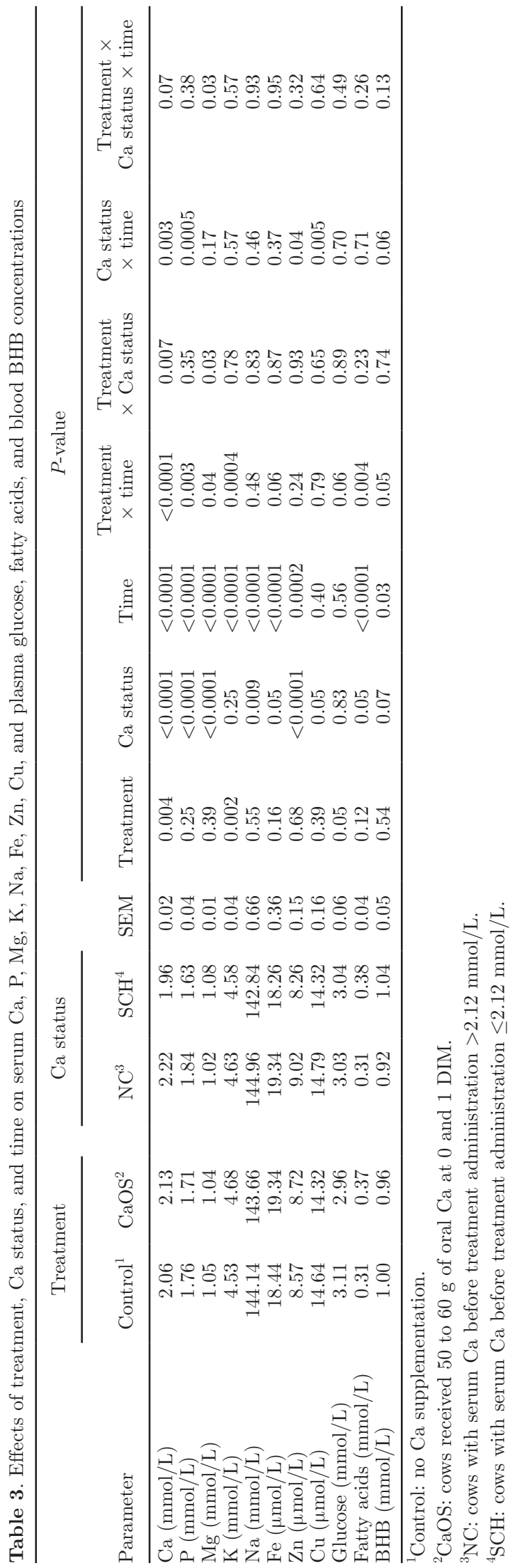

Thus, factors other than the gastrointestinal concentration gradient may also affect treatment response in cows with subclinical hypocalcemia.

At 2 DIM an interaction of Ca status, treatment, and time $(P=0.03)$ was observed; serum Ca concentration was higher for control-NC cows $(2.28 \mathrm{mmol} / \mathrm{L})$ compared with control-SCH $(2.06 \mathrm{mmol} / \mathrm{L} ; P=0.003)$ and CaOS-SCH cows $(2.09 \mathrm{mmol} / \mathrm{L} ; P=0.01)$, and numerically higher compared with $\mathrm{CaOS}-\mathrm{NC}$ cows $(2.13 \mathrm{mmol} / \mathrm{L} ; P=0.13)$. It is plausible that supplementing $\mathrm{Ca}$ to normocalcemic cows downregulates $\mathrm{Ca}$ metabolism and delays the activation of postpartum Ca homeorhetic mechanisms (Rosol et al., 1995; Blanc et al., 2014). However, this observation should be carefully interpreted as the sample size at 2 DIM was limited to 7 and 11 cows for CaOS-NC and control-NC, respectively.

\section{Subclinical Hypocalcemia}

Effects of Ca status $(P<0.001)$, treatment $(P=$ $0.05)$, time $(P<0.001)$, and their interactions were observed on subclinical hypocalcemia prevalence (Figure 3). The prevalence of subclinical hypocalcemia was lower for CaOS than control cows at 0 DIM $+1 \mathrm{~h}(32$ vs. $71 \% ; P<0.001)$ and at $1 \mathrm{DIM}+1 \mathrm{~h}(41$ vs. $64 \%$; $P<0.01$ ), but no differences were observed at 1 DIM (68 vs. $77 \%$ ). In contrast, at $2 \mathrm{DIM}$, the prevalence of subclinical hypocalcemia tended to be higher for CaOS than control cows (70 vs. $44 \% ; P=0.08$ ); this effect was mostly driven by a tendency to a higher prevalence of subclinical hypocalcemia for CaOS-NC compared with control-NC cows (70 vs. $25 \% ; P=0.07$ ).

\section{Urine $\mathrm{pH}$}

Treatment $(P<0.001)$ and treatment $\times$ time $(P$ $=0.02$ ) effects were observed on urine $\mathrm{pH}$ (Figure 4). Cows in CaOS group had lower urine $\mathrm{pH}$ than control cows at 1 DIM (6.2 vs. 7.2$)$ and 1 DIM $+1 \mathrm{~h}$ (5.8 vs. 7.2). A decrease in urine $\mathrm{pH}$ was expected due to the acidifying effect of the Ca sources $\left(\mathrm{CaCl}_{2}\right.$ and $\left.\mathrm{CaSO}_{4}\right)$ included in the oral Ca formulation (Goff et al., 2004). Urine $\mathrm{pH}$ acidification is a compensatory response of the kidney to maintain blood $\mathrm{pH}$ within the normal range and is an indicator of body acid-base status. Previous studies have also shown a decrease in urine $\mathrm{pH}$ after oral Ca supplementation (Sampson et al., 2009; Blanc et al., 2014); nonetheless, Martinez et al. (2016) reported no effect of oral Ca supplementation with $86 \mathrm{~g}$ of $\mathrm{Ca}$ as $\mathrm{CaCl}_{2}$ and $\mathrm{CaSO}_{4}$ on blood $\mathrm{pH}$.

The acidification could benefit cows with subclinical hypocalcemia by improving tissue sensitivity to parathormone (PTH) that will enhance renal production 
of 1,25-dihydroxyvitamin D and, consequently, favor active intestinal $\mathrm{Ca}$ absorption and reduce urinary $\mathrm{Ca}$ excretion (Goff et al., 2014). Mean urine $\mathrm{pH}$ reached its nadir at $1 \mathrm{DIM}+1 \mathrm{~h}$ with 5.8 . This urine $\mathrm{pH}$ was above the 5.5 critical threshold indicative of uncompensated metabolic acidosis that may have detrimental effects on intake of close-up cows.

\section{Serum Phosphorus}

By Treatment and Time. Time and treatment $\times$ time effects were observed on serum $\mathrm{P}$ concentration (Table 3). Serum P concentration increased after calving. The increase in serum $\mathrm{P}$ concentration from 1 DIM to $1 \mathrm{DIM}+1 \mathrm{~h}$ was more obvious for $\mathrm{CaOS}(0.08$ $\mathrm{mmol} / \mathrm{L} ; P<0.001)$ than control $(0.003 \mathrm{mmol} / \mathrm{L} ; P=$ $0.9)$ cows; however, at $2 \mathrm{DIM}$, serum $\mathrm{P}$ concentration tended to be lower $(P=0.08)$ for CaOS compared with control cows. Based on prior studies, the effects of $\mathrm{Ca}$ supplementation on serum $\mathrm{P}$ concentration are unclear. Melendez et al. (2002) observed a decrease in plasma $\mathrm{P}$ concentration when $\mathrm{CaCl}_{2}$ was administered orally, whereas other authors reported no effects on serum $\mathrm{P}$ concentration either with $\mathrm{CaCl}_{2}$ orally (Dhiman and Sasidharan, 1999) or Ca borogluconate subcutaneously (Amanlou et al., 2016). In our study, the immediate acidification after treatment administration could have enhanced the efficiency of $\mathrm{P}$ absorption from 1 DIM to 1 DIM $+1 \mathrm{~h}$, whereas cows were restrained in headlocks with access to fresh feed; however, oral Ca supplementation may have had a negative effect on PTH activity and consequently on kidney production of 1,25-dihydroxyvitamin $\mathrm{D}$, leading to a reduced intestinal absorption of $\mathrm{P}$ in CaOS cows.

By Initial Ca Status. Calcium status and Ca status $\times$ time effects were observed on serum $\mathrm{P}$ concentration (Table 3; Figure 5). Lower serum $\mathrm{P}$ concentration was observed for SCH than NC cows at 0 (1.05 vs. 1.46 $\mathrm{mmol} / \mathrm{L} ; P<0.001)$ and 1 DIM (1.65 vs. $1.96 \mathrm{mmol} / \mathrm{L}$; $P<0.001)$; however, no differences were observed at 2 DIM.

\section{Serum Magnesium}

By Treatment and Time. Time and treatment $\times$ time effects were observed on serum $\mathrm{Mg}$ concentra-

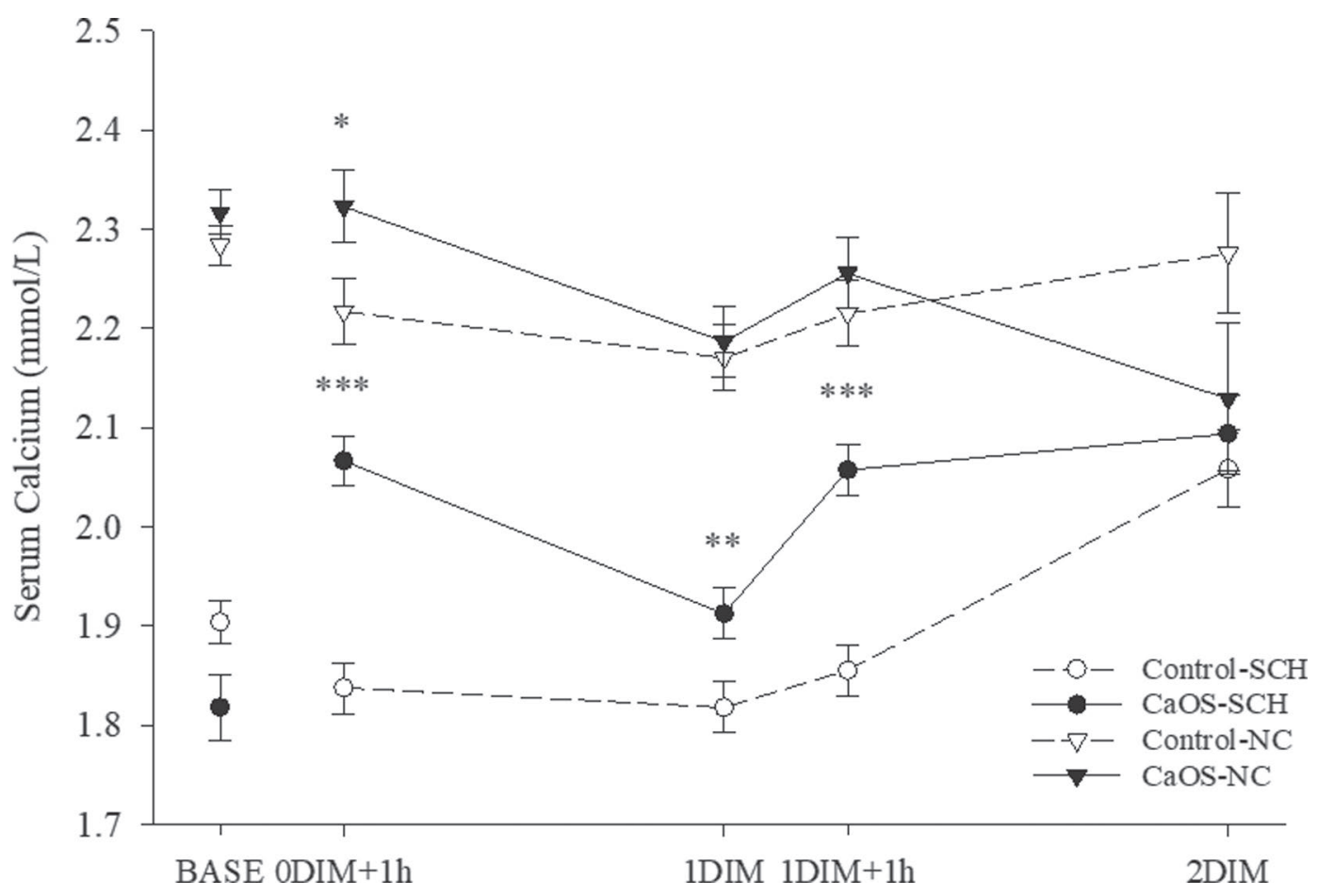

Figure 2. Total serum Ca (LSM $\pm \mathrm{SEM})$ in multiparous Jersey cows with subclinical hypocalcemia $(\mathrm{SCH} ; \mathrm{Ca} \leq 2.12 \mathrm{mmol} / \mathrm{L})$ and normocalcemia (NC; $\mathrm{Ca}>2.12 \mathrm{mmol} / \mathrm{L}$ ) at calving, for control (no oral Ca supplementation) and treatment (CaOS; 50 to $60 \mathrm{~g}$ of oral Ca at 0 and 1 DIM); control-SCH $(\mathrm{n}=66)$, CaOS-SCH $(\mathrm{n}=66)$, control-NC $(\mathrm{n}=39)$, and CaOS-NC $(\mathrm{n}=34)$. Fixed effects in the statistical model: covariate $(P<0.001)$, treatment $(P=0.004)$, time $(P<0.001)$, initial calcemic status $($ Ca status; $P<0.001)$, treatment $\times$ time $(P<0.001)$, Ca status $\times$ treatment $(P=0.007)$, Ca status $\times$ time $(P=0.003)$, and Ca status $\times$ time $\times$ treatment $(P=0.07)$. Base represents serum Ca concentration (mean \pm SEM) before treatment at 0 DIM. Control-SCH versus CaOS-SCH differences are indicated by $* P<0.001$ and $\ddagger P=0.01$. Control-NC versus CaOS-NC differences are indicated by $\dagger P=0.03$. ${ }^{*}$ At 0 DIM $+1 \mathrm{~h}$, control-NC and CaOS-NC differ $(P=0.03)$. $* *$ Within 0 DIM, control-SCH and CaOS-SCH differ $(P=0.01)$. ${ }^{* * * A t} 0 \mathrm{DIM}+1 \mathrm{~h}$ and $1 \mathrm{DIM}+1 \mathrm{~h}$, control-SCH and CaOS-SCH differ $(P<0.001)$. 


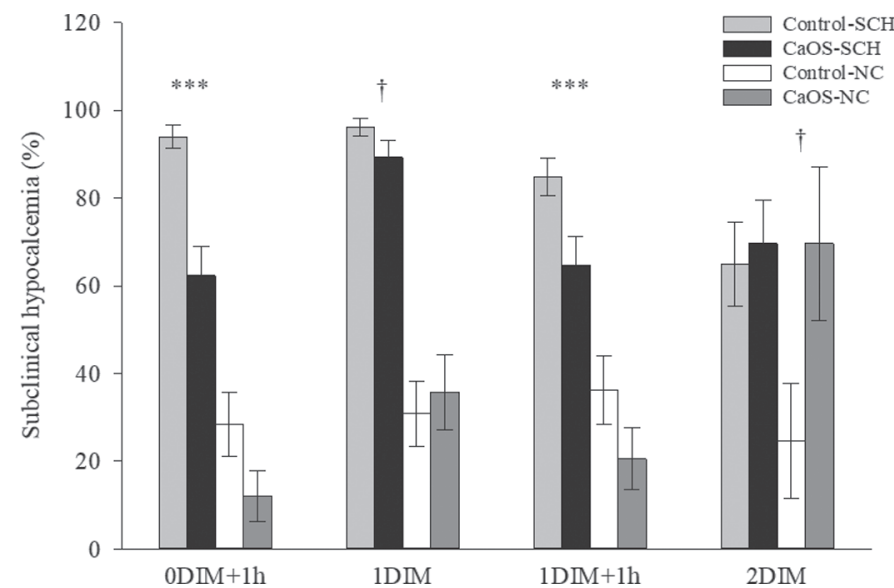

Figure 3. Daily prevalence of subclinical hypocalcemia (SCH; LSM $\pm \mathrm{SEM})$ in multiparous Jersey cows with $\mathrm{SCH}(\mathrm{Ca} \leq 2.12 \mathrm{mmol} / \mathrm{L})$ and normocalcemia ( $\mathrm{NC} ; \mathrm{Ca}>2.12 \mathrm{mmol} / \mathrm{L}$ ) at calving, for control (no oral Ca supplementation) and treatment (CaOS; 50 to $60 \mathrm{~g}$ of oral Ca at 0 and 1 DIM); control-SCH $(\mathrm{n}=66)$, CaOS-SCH $(\mathrm{n}=66)$, control-NC $(\mathrm{n}=39)$, and CaOS-NC $(\mathrm{n}=34)$. Fixed effects in the statistical model: covariate $(P<0.001)$, treatment $(P=0.05)$, time $(P<0.001)$, initial calcemic status $($ Ca status; $P<0.001)$, treatment $\times$ time $(P=0.002)$, Ca status $\times$ treatment $(P=0.03)$, Ca status $\times$ time $(P<0.001)$, and Ca status $\times$ time $\times$ treatment $(P=0.50)$. Base represents the prevalence of subclinical hypocalcemia before treatment at 0 DIM. Control-SCH versus CaOS-SCH differences are indicated by $* P<0.001, \pm P=0.01$, and $\dagger P=0.09$. Control-NC versus CaOS-NC differences are indicated by $\S P=0.07$. $\dagger$ At 1 DIM, control-SCH and CaOS-SCH differ $(P=0.09)$; at 2 DIM, control-NC and CaOS-NC differ $(P=0.07)$. ${ }^{* * A t} 1 \mathrm{DIM}+1 \mathrm{~h}$, control-SCH and CaOS-SCH differ $(P=0.01)$. ${ }^{* *}$ At 0 DIM $+1 \mathrm{~h}$, control-SCH and CaOS-SCH differ $(P<0.001)$.

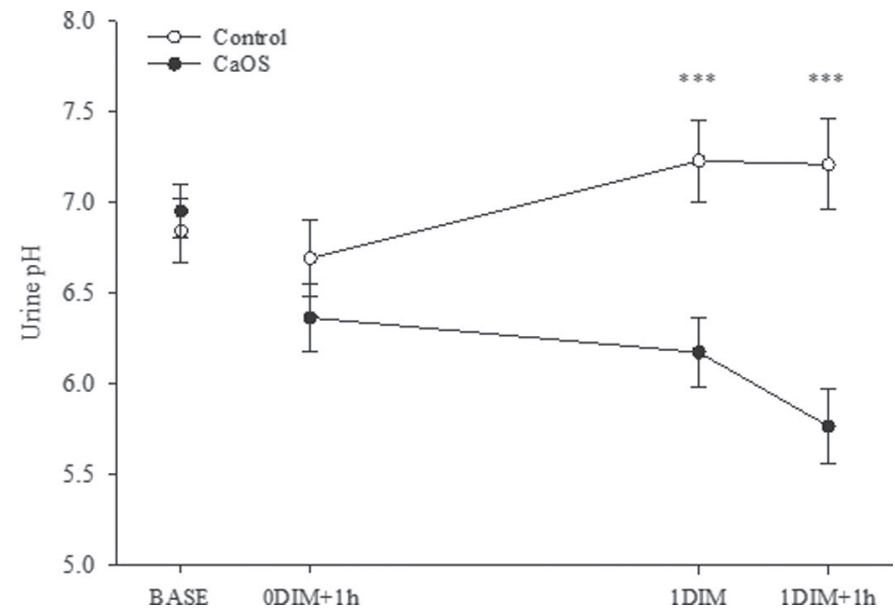

Figure 4. Urine $\mathrm{pH}(\mathrm{LSM} \pm \mathrm{SEM})$ in multiparous Jersey cows for control (no oral Ca supplementation; $\mathrm{n}=46$ ) and treatment $(\mathrm{CaOS}$; 50 to $60 \mathrm{~g}$ of oral $\mathrm{Ca}$ at 0 and $1 \mathrm{DIM} ; \mathrm{n}=50)$. Fixed effects in the statistical model: covariate $(P<0.001)$, treatment $(P<0.001)$, and treatment $\times$ time $(P=0.02)$. Base represents urine $\mathrm{pH}$ measurements (mean $\pm \mathrm{SEM}$ ) before treatment at 0 DIM. Control versus CaOS differences are indicated by $* P<0.001$. ${ }^{* * * A t} 1$ DIM and 1 DIM $+1 \mathrm{~h}$, control and CaOS differ $(P<0.001)$.
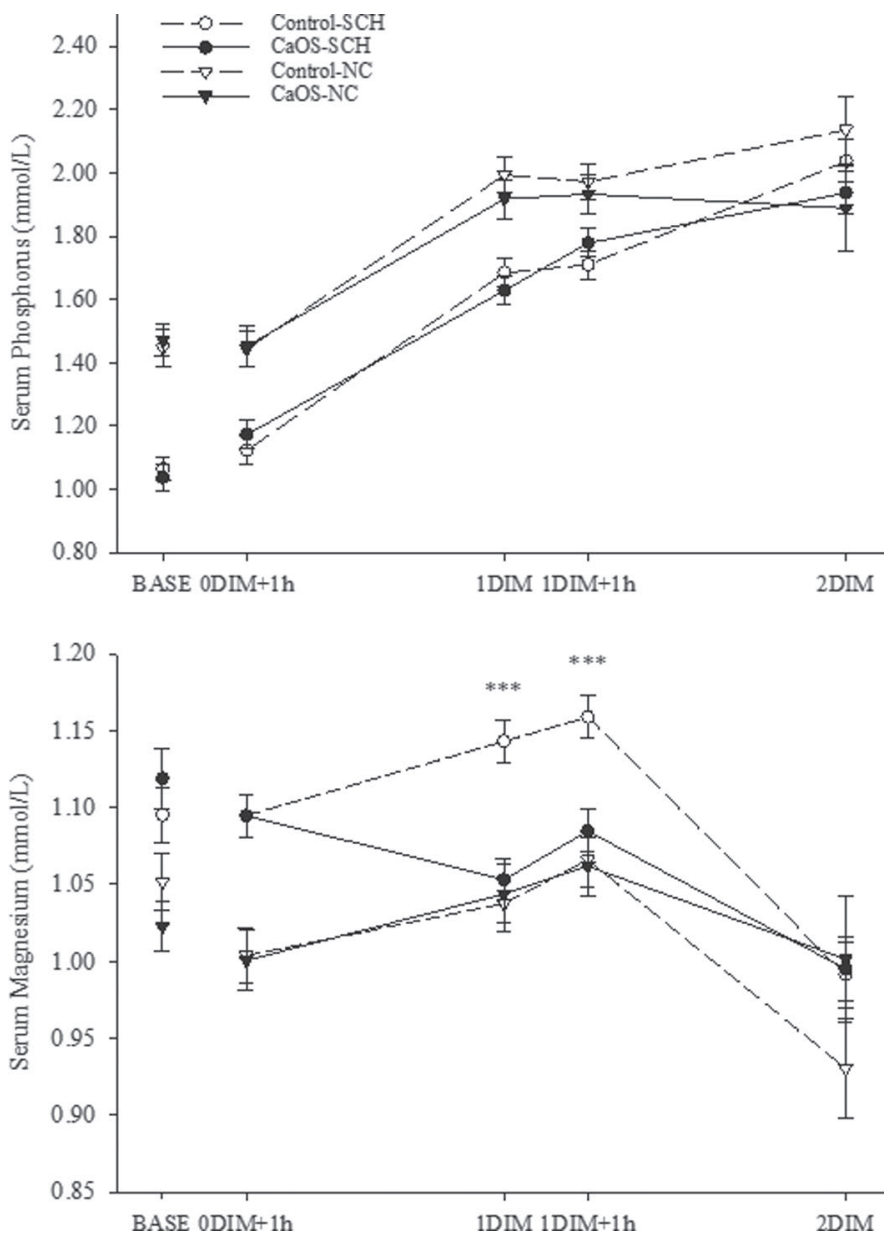

Figure 5. Serum $\mathrm{P}$ and $\mathrm{Mg}$ concentration (LSM $\pm \mathrm{SEM}$ ) in multiparous Jersey cows with subclinical hypocalcemia ( $\mathrm{SCH}$; $\mathrm{Ca} \leq 2.12$ $\mathrm{mmol} / \mathrm{L}$ ) and normocalcemia (NC; Ca $>2.12 \mathrm{mmol} / \mathrm{L}$ ) at calving, for control (no oral Ca supplementation) and treatment (CaOS; 50 to 60 $\mathrm{g}$ of oral Ca at 0 and 1 DIM); control-SCH $(\mathrm{n}=66)$, CaOS-SCH $(\mathrm{n}=$ $66)$, control-NC $(\mathrm{n}=39)$, and CaOS-NC $(\mathrm{n}=34)$. Fixed effects in the statistical model for $\mathrm{P}$ : covariate $(P<0.001)$, treatment $(P=0.25)$, time $(P<0.001)$, calcemic status (Ca status; $P<0.001)$, treatment $\times$ time $(P=0.003)$, Ca status $\times$ treatment $(P=0.35)$, Ca status $\times$ time $(P<0.001)$, and Ca status $\times$ time $\times$ treatment $(P=0.38)$. Fixed effects in the statistical model for $\mathrm{Mg}$ : covariate $(P<0.001)$, treatment $(P=0.04)$, time $(P<0.001)$, initial Ca status $(P<0.001)$, treatment $\times$ time $(P=0.04)$, Ca status $\times$ treatment $(P=0.03)$, Ca status $\times$ time $(P=0.17)$, and Ca status $\times$ time $\times$ treatment $(P=0.03)$. Base represents serum $\mathrm{P}$ and $\mathrm{Mg}$ concentration (mean \pm SEM) before treatment at 0 DIM. ${ }^{* * * A t} 1$ DIM and 1 DIM $+1 \mathrm{~h}$, control-SCH and CaOS-SCH differ $(P<0.001)$.

tion (Table 3). Serum Mg concentration decreased postpartum; however, despite the general downward trend in serum $\mathrm{Mg}$ concentration, an increase of 0.02 $\mathrm{mmol} / \mathrm{L}$ was observed from 1 DIM to 1 DIM $+1 \mathrm{~h}(P$ $<0.001)$. Serum $\mathrm{Mg}$ concentration was lower for CaOS than control cows at 1 DIM $(1.05$ vs. $1.09 \mathrm{mmol} / \mathrm{L} ; P$ $=0.01)$ and $1 \mathrm{DIM}+1 \mathrm{~h}(1.07$ vs. $1.11 \mathrm{mmol} / \mathrm{L} ; P$ $=0.02)$, but no differences were detected at 2 DIM. These treatment differences were minor $(0.04 \mathrm{mmol} / \mathrm{L})$ 
and serum $\mathrm{Mg}$ concentration was within physiological concentration (0.78 to $1.19 \mathrm{mmol} / \mathrm{L}$; Martín-Tereso and Martens, 2014). Therefore, biological implications were most likely minimal. Lower serum $\mathrm{Mg}$ concentration in $\mathrm{CaOS}$ cows may be explained by direct competition of both ions ( $\mathrm{Ca}$ and $\mathrm{Mg}$ ) during reabsorption by paracellular mechanisms, and by a possible decrease of PTH stimulation that would promote kidney Mg excretion in CaOS cows (Goff, 2004). Melendez et al. (2002) observed no effects of postpartum Ca supplementation on blood Mg concentration. However, Martinez et al. (2016) reported lower blood $\mathrm{Mg}$ concentration in oral Ca supplemented primiparous cows during the first 2 DIM, but no treatment effects were detected in multiparous cows.

By Initial Ca Status. There were effects of Ca status and its interactions with treatment and treatment $\times$ time on serum $\mathrm{Mg}$ concentration (Table 3; Figure 5). No treatment effect on serum $\mathrm{Mg}$ concentration was detected for $\mathrm{NC}$ cows. However, control-SCH had higher serum $\mathrm{Mg}$ concentration than CaOS-SCH cows at 1 DIM (1.14 vs. $1.05 \mathrm{mmol} / \mathrm{L} ; P<0.001)$ and $1 \mathrm{DIM}+1$ h $(1.16$ vs. $1.09 \mathrm{mmol} / \mathrm{L} ; P<0.001)$. A possible explanation may be an increased synthesis and stimulation of PTH in control-SCH cows compared with NC and CaOS-SCH cows (Rosol et al., 1995); PTH stimulation enhances kidney $\mathrm{Mg}$ reabsorption, raising serum $\mathrm{Mg}$ concentration (Goff, 2004). In agreement, Martinez et al. (2014) observed that cows induced with SCH had higher plasma $\mathrm{Mg}$ concentration.

\section{Serum $\mathrm{K}, \mathrm{Na}, \mathrm{Fe}, \mathrm{Zn}$, and $\mathrm{Cu}$}

By Treatment and Time. No treatment effect was detected on serum $\mathrm{Na}, \mathrm{Fe}, \mathrm{Zn}$, and $\mathrm{Cu}$ concentrations (Table 3). There were effects of treatment and time on serum $\mathrm{K}$ concentration, and treatment $\times$ time on serum K and Fe concentrations. Serum Fe concentration tended to be higher in CaOS compared with control cows at 2 DIM (23.10 vs. $20.41 \mu \mathrm{mol} / \mathrm{L} ; P=0.08)$. Overall, serum K concentration increased over time; this increase was of $0.13(P=0.01)$ and $0.08 \mathrm{mmol} / \mathrm{L}$ $(P=0.06)$ from 1 DIM to $1 \mathrm{DIM}+1 \mathrm{~h}$ for $\mathrm{CaOS}$ and control cows, respectively. Serum K concentration was higher in CaOS than control cows (4.68 vs. 4.53 $\mathrm{mmol} / \mathrm{L} ; P=0.002)$; nevertheless, serum $\mathrm{K}$ concentration was within the normal range $(3.9$ to $5.8 \mathrm{mmol} / \mathrm{L}$; Goff, 2004) and biological implications may be minimal. A possible transient acidifying effect of oral Ca boluses (Figure 4) could partially explain the difference observed on serum $\mathrm{K}$ concentration. When cows undergo metabolic acidosis, an exchange of intracellular $\mathrm{K}^{+}$for extracellular $\mathrm{H}^{+}$occurs, producing hyperkalemia (Adrogué and Madias, 1981; Goff, 2004; Russell and Roussel, 2007). In contrast, Martinez et al. (2016) found no treatment effects of oral Ca supplementation in blood $\mathrm{K}$ concentration.

By Initial Ca Status. Effects of Ca status were observed on serum $\mathrm{Na}, \mathrm{Fe}, \mathrm{Zn}$, and $\mathrm{Cu}$ concentrations and Ca status $\times$ time on serum $\mathrm{Cu}$ and $\mathrm{Zn}$ concentrations. Cows classified as $\mathrm{SCH}$ had lower serum $\mathrm{Na}, \mathrm{Fe}, \mathrm{Zn}$, and $\mathrm{Cu}$ concentrations than NC cows (Tables 2 and 3). Over time, serum $\mathrm{Zn}$ and $\mathrm{Cu}$ concentrations decreased for $\mathrm{NC}$ [Zn (10.40 to $9.02 \mu \mathrm{mol} / \mathrm{L}) ; \mathrm{Cu}(15.42$ to 14.16 $\mu \mathrm{mol} / \mathrm{L})]$ and increased for SCH cows [Zn (8.41 to 9.02 $\mu \mathrm{mol} / \mathrm{L}) ; \mathrm{Cu}(14.32$ to $14.79 \mu \mathrm{mol} / \mathrm{L})]$. The biological implications of the differences in mineral concentrations with Ca status observed in the present study are unknown and warrant further analysis.

\section{Plasma Glucose}

By Treatment and Time. There were treatment and treatment $\times$ time effects on plasma glucose concentration (Table 3). At 1 DIM, plasma glucose concentration was lower for $\mathrm{CaOS}$ than control cows (2.91 vs. $3.14 \mathrm{mmol} / \mathrm{L} ; P=0.008)$, but no treatment differences were observed at 2 DIM (3.08 vs. $3.01 \mathrm{mmol} / \mathrm{L})$. Previous studies did not report treatment effects on glucose concentration after either oral, subcutaneous, or intravenous postpartum Ca supplementation (Melendez et al., 2002; Amanlou et al., 2016; Martinez et al., 2016).

Our findings follow the pattern of an inverse relationship between plasma $\mathrm{Ca}$ and glucose concentrations in postpartum cows (Larsen et al., 2001); at 1 DIM serum Ca concentration was higher and glucose concentration was lower for CaOS cows. Pancreatic $\beta$-cells require Ca stimulation to release insulin (Rorsman and Trube, 1986); the higher serum Ca concentration observed in CaOS cows may have led to a greater insulin secretion and, subsequently, lower plasma glucose concentration for CaOS cows. In addition, this treatment effect may partially be explained by a possible transient decrease of DMI due to the acidifying effects of the oral $\mathrm{Ca}$ boluses. The long-term implications of these differences in postpartum glucose concentration are unclear. Some studies have associated higher postpartum glucose concentration at 3 DIM with pregnancy success at first insemination (Garverick et al., 2013). However, other researchers found that elevated postpartum glucose concentration at 3 DIM was associated with increased odds of being diagnosed with metritis $(>3.14 \mathrm{mmol} / \mathrm{L})$ and clinical endometritis $(>2.52 \mathrm{mmol} / \mathrm{L}$; Bicalho et al., 2017).

By Initial Ca Status. No effect of Ca status or its interactions were detected on plasma glucose concentration. Nevertheless, SCH cows had greater plasma glucose concentration than $\mathrm{NC}$ cows before first oral $\mathrm{Ca}$ 
dose administration $(4.65$ vs. $3.71 \mathrm{mmol} / \mathrm{L} ; P=0.02$; Table 2).

\section{Plasma Fatty Acids}

By Treatment and Time. Time and treatment $\times$ time effects were observed on plasma fatty acid concentrations (Table 3). Fatty acids increased from 0.29 (1 DIM) to $0.39 \mathrm{mmol} / \mathrm{L}(2 \mathrm{DIM} ; P<0.001)$. No differences between CaOS and control cows were observed on fatty acid concentrations at 1 DIM (0.28 vs. $0.29 \mathrm{mmol} / \mathrm{L})$, but at 2 DIM fatty acid concentrations were higher for CaOS than control cows (0.43 vs. $0.35 \mathrm{mmol} / \mathrm{L} ; P=0.02)$. Similarly, Martinez et al. (2016) found higher fatty acid concentrations in oral Ca supplemented than control cows on $\mathrm{d} 1$ and 2 postpartum.

Elevated postpartum serum fatty acid concentrations at 3 to 14 DIM may be a predictor of health disorders (>0.57 mmol/L; Ospina et al., 2010). However, Chapinal et al. (2012) observed higher milk production when serum fatty acids were $\geq 0.50 \mathrm{mmol} / \mathrm{L}$. In our study, the proportion of cows with plasma fatty acid concentrations above the $0.57 \mathrm{mmol} / \mathrm{L}$ threshold at 2 DIM did not differ between CaOS and control cows (14.3 vs. $15.6 \% ; P=0.88$ ), and overall plasma fatty acid concentrations for both groups were below the aforementioned threshold. Our results suggest that energy balance during the first 2 DIM may be lower in CaOS compared with control cows. This could be explained by either increased production and energy requirements for lactation or a reduction in intake for CaOS. Amanlou et al. (2016) observed greater DMI $24 \mathrm{~h}$ after calving when cows were administered $\mathrm{Ca}$ by subcutaneous route; however, in our study, Ca was administered orally and the $\mathrm{Ca}$ salts included in the bolus formulation likely drove the dietary cation-anion difference away from the desired 25 to $30 \mathrm{mEq} / 100 \mathrm{~g}$ of DM to maximize intake of lactating cows (Beede, 2005).

By Initial Ca Status. Plasma fatty acid concentrations were higher for SCH than $\mathrm{NC}$ cows $(0.38$ vs. 0.30 $\mathrm{mmol} / \mathrm{L} ; P=0.03)$. However, Ca status $\times$ time and $\mathrm{Ca}$ status $\times$ treatment effects were not significant.

\section{Blood BHB}

By Treatment and Time. Time and treatment $\times$ time effects were observed on blood BHB concentration (Table 3). Over time, blood BHB concentration decreased for CaOS $(1.0,1.0$, and $0.9 \pm 0.04 \mathrm{mmol} / \mathrm{L}$ at 5,8 , and 11 DIM, respectively) but not for control cows $(1.0,1.0$, and $1.0 \pm 0.04 \mathrm{mmol} / \mathrm{L}$ at 5,8 , and 11 DIM, respectively). This difference is small and may not have biological implications. Prior research found no treatment effect on blood BHB concentration after oral (Melendez et al., 2002; Oetzel and Miller, 2012; Martinez et al., 2016), subcutaneous (Amanlou et al., 2016; Miltenburg et al., 2016), or intravenous (Melendez et al., 2002) Ca supplementation.

By Initial Ca Status. A tendency was observed for greater blood $\mathrm{BHB}$ concentration in $\mathrm{SCH}$ compared with $\mathrm{NC}$ cows and a trend for a Ca status $\times$ time effect on blood BHB concentration (Table 3). At 8 DIM, higher blood $\mathrm{BHB}$ concentration was observed for $\mathrm{SCH}$ than NC cows (0.9 vs. $1.0 \mathrm{mmol} / \mathrm{L} ; P=0.007)$.

\section{Subclinical Ketosis}

Using a previously defined subclinical ketosis threshold for blood BHB concentration of $\geq 1.2 \mathrm{mmol} / \mathrm{L}$ (LeBlanc et al., 2005), the proportion of cows above the threshold at least once during the sampling period did not differ between $\mathrm{CaOS}$ and control cows (36 vs. $41 \% ; P=0.47$ ), and $\mathrm{NC}$ and $\mathrm{SCH}$ cows (32 vs. $42 \%$; $P=0.12$ ). However, when analyzing incidence controlling for sampling day, an overall effect of Ca status on subclinical ketosis incidence $(P=0.006)$ was observed; prevalence was greater for $\mathrm{SCH}$ compared with $\mathrm{NC}$ cows at 8 DIM ( 28 vs. $10 \% ; P=0.002$ ).

\section{Postpartum Health Disorders}

The present study was not designed to evaluate treatment effects of postpartum health disorders; thus, differences were not evaluated statistically and only descriptive data are presented. Signs of postpartum health disorders were detected on $9.8 \%$ of enrolled cows [CaOS $(\mathrm{n}=8)$, control $(\mathrm{n}=12)]$ including fever $[\mathrm{CaOS}$ $(\mathrm{n}=4)$, control $(\mathrm{n}=5)]$, retained placenta $[\mathrm{CaOS}(\mathrm{n}=$ $2)$, control $(\mathrm{n}=3)]$, metritis [CaOS $(\mathrm{n}=2)$, control (n $=2)]$, and digestive disorders $[\mathrm{CaOS}(\mathrm{n}=1)$, control $(\mathrm{n}=2)]$. The prevalence of purulent vaginal discharge was 11 and $9 \%$ for CaOS and control cows, respectively.

\section{CONCLUSIONS}

Postpartum oral supplementation with 2 doses of 50 to $60 \mathrm{~g}$ of $\mathrm{Ca}$ increased serum $\mathrm{Ca}$ concentration and reduced the prevalence of subclinical hypocalcemia. Initial calcemic status highly influenced treatment effects, with $\mathrm{SCH}$ cows showing a greater serum Ca concentration increase after supplementation than $\mathrm{NC}$ cows. However, oral Ca supplementation seemed to disrupt $\mathrm{Ca}$ homeorhetic mechanisms in normocalcemic cows. Future studies should evaluate the long-term implications on production and reproduction of oral $\mathrm{Ca}$ supplementation on NC and SCH Jersey cows. 


\section{ACKNOWLEDGMENTS}

Financial support for this research was provided by Bio-Vet Inc. (Barneveld, WI). The authors appreciate the collaboration of Jer-Z-Boyz Ranch (Pixley, CA) in allowing us to use their facilities, cows and records. Special appreciation is extended to Diego Rolle, Anwar Belaid, Sonia Rodríguez, Sebastian Castaño, and Victor José Ramírez (Veterinary Medicine Teaching and Research Center, Tulare, CA) for their work during the sample collection period.

\section{REFERENCES}

Adrogué, H. J., and N. E. Madias. 1981. Changes in plasma potassium concentration during acute acid-base disturbances. Am. J. Med. 71:456-467.

Amanlou, H., A. P. Akbari, N. E. Farsuni, and N. Silva-del-Río. 2016. Effects of subcutaneous calcium administration at calving on mineral status, health, and production of Holstein cows. J. Dairy Sci. 99:9199-9210. https://doi.org/10.3168/jds.2015-10844.

Beede, D. K. 2005. Formulation of rations with optimal cations and anions (DCAD) for lactation. Pages $93-112$ in Proc. Tri-Sate Dairy Nutr. Conf., Fort Wayne, IN. The Ohio State University, Columbus.

Bicalho, M. L. S., E. C. Marques, R. O. Gilbert, and R. C. Bicalho. 2017. The association of plasma glucose, BHBA, and NEFA with postpartum uterine diseases, fertility, and milk production of Holstein dairy cows. Theriogenology 88:270-282. https://doi.org/10 .1016/j.theriogenology.2016.09.036.

Blanc, C. D., M. Van der List, S. S. Aly, H. A. Rossow, and N. Silvadel-Río. 2014. Blood calcium dynamics after prophylactic treatment of subclinical hypocalcemia with oral or intravenous calcium. J. Dairy Sci. 97:6901-6906. https://doi.org/10.3168/jds.2014-7927.

Brady, M. D. 2013. A survey of calcium status of dairy cattle residing in California's Central Valley. MS Thesis. Jordan College of Agricultural Sciences and Technology, California State University, Fresno.

Bronner, F., and D. Pansu. 1999. Nutritional aspects of calcium absorption. J. Nutr. 129:9-12.

Bronner, F., D. Pansu, and W. D. Stein. 1986. An analysis of intestinal calcium transport across the rat intestine. Am. J. Physiol. 250:G561-G569

Carroll, J. J., N. Smith, and A. L. Babson. 1970. A colorimetric serum glucose determination using hexokinase and glucose-6-phosphate dehydrogenase. Biochem. Med. 4:171-180.

Chamberlin, W. G., J. R. Middleton, J. N. Spain, G. C. Johnson, M. R. Ellersieck, and P. Pithua. 2013. Subclinical hypocalcemia, plasma biochemical parameters, lipid metabolism, postpartum disease, and fertility in postparturient dairy cows. J. Dairy Sci. 96:7001-7013. https://doi.org/10.3168/jds.2013-6901.

Chapinal, N., M. Carson, T. F. Duffield, M. Capel, S. Godden, M. W. Overton, J. E. P. Santos, and S. J. LeBlanc. 2011. The association of serum metabolites with clinical disease during the transition period. J. Dairy Sci. 94:4897-4903. https://doi.org/10.3168/jds 2010-4075.

Chapinal, N., M. E. Carson, S. J. LeBlanc, K. E. Leslie, S. Godden, M. Capel, J. E. P. Santos, M. W. Overton, and T. F. Duffield. 2012. The association of serum metabolites in the transition period with milk production and early-lactation reproductive performance. J. Dairy Sci. 95:1301-1309. https://doi.org/10.3168/jds.2011-4724.

Charbonneau, E., D. Pellerin, and G. R. Oetzel. 2006. Impact of lowering dietary cation-anion difference in nonlactating dairy cows: A meta-analysis. J. Dairy Sci. 89:537-548. https://doi.org/10.3168/ jds.S0022-0302(06)72116-6.
Dhiman, T. R., and V. Sasidharan. 1999. Effectiveness of calcium chloride in increasing blood calcium concentrations of periparturient dairy cows. J. Anim. Sci. 77:1597-1605.

Ferguson, J. D., D. T. Galligan, and N. Thomsen. 1994. Principal descriptors of body condition score in Holstein cows. J. Dairy Sci. 77:2695-2703. https://doi.org/10.3168/jds.S0022-0302(94)77212 -X.

Garverick, H. A., M. N. Harris, R. Vogel-Bluel, J. D. Sampson, J. Bader, W. R. Lamberson, J. N. Spain, M. C. Lucy, and R. S. Youngquist. 2013. Concentrations of nonesterified fatty acids and glucose in blood of periparturient dairy cows are indicative of pregnancy success at first insemination. J. Dairy Sci. 96:181-188. https://doi.org/10.3168/jds.2012-5619.

Goff, J. P. 2004. Macromineral disorders of the transition cow. Vet. Clin. North Am. Food Anim. Pract. 20:471-494. https://doi.org/ 10.1016/j.cvfa.2004.06.003.

Goff, J. P., A. Liesengang, and R. L. Horst. 2014. Diet-induced pseudohypoparathyroidism: A hypocalcemia and milk fever risk factor. J. Dairy Sci. 97:1520-1528. https://doi.org/10.3168/jds.2013 $-7467$.

Goff, J. P., T. A. Reinhardt, and R. L. Horst. 1995. Milk fever and dietary cation-anion balance effects on concentration of vitamin D receptor in tissue of periparturient dairy cows. J. Dairy Sci. 78:2388-2394. https://doi.org/10.3168/jds.S0022-0302(95)76867 $-9$.

Goff, J. P., R. Ruiz, and R. L. Horst. 2004. Relative acidifying activity of anionic salts commonly used to prevent milk fever. J. Dairy Sci. 87:1245-1255. https://doi.org/10.3168/jds.S0022-0302(04)73275 $-0$.

Grabherr, H., M. Spolders, M. Fürll, and G. Flachowsky. 2009. Effect of several doses of zeolite A on feed intake, energy metabolism and on mineral metabolism in dairy cows around calving. J. Anim. Physiol. Anim. Nutr. (Berl.) 93:221-236. https://doi.org/10.1111/ j.1439-0396.2008.00808.x.

Iwersen, M., U. Falkenberg, R. Voigtsberger, D. Forderung, and W. Heuwieser. 2009. Evaluation of an electronic cowside test to detect subclinical ketosis in dairy cows. J. Dairy Sci. 92:2618-2624. https://doi.org/10.3168/jds.2008-1795.

Kehoe, S. I., B. M. Jayarao, and A. J. Heinrichs. 2007. A survey of bovine colostrum composition and colostrum management practices on Pennsylvania dairy farms. J. Dairy Sci. 90:4108-4116. https:// doi.org/10.3168/jds.2007-0040.

Larsen, T., G. Møller, and R. Bellio. 2001. Evaluation of clinical and clinical chemical parameters in periparturient cows. J. Dairy Sci. 84:1749-1758. https://doi.org/10.3168/jds.S0022-0302(01)74610 $-3$.

Lean, I. J., P. J. DeGaris, D. M. McNeil, and E. Block. 2006. Hypocalcemia in dairy cows: meta-analysis and dietary cation anion difference theory revisited. J. Dairy Sci. 89:669-684. https://doi .org/10.3168/jds.S0022-0302(06)72130-0.

LeBlanc, S. J., K. E. Leslie, and T. F. Duffield. 2005. Metabolic predictors of displaced abomasum in dairy cattle. J. Dairy Sci. 88:159-170. https://doi.org/10.3168/jds.S0022-0302(05)72674-6.

Martín-Tereso, J., and H. Martens. 2014. Calcium and magnesium physiology and nutrition in relation to the prevention of milk fever and tetany (dietary management of macrominerals in preventing disease). Vet. Clin. North Am. Food Anim. Pract. 30:643-670. https://doi.org/10.1016/j.cvfa.2014.07.007.

Martinez, N., C. A. Risco, F. S. Lima, R. S. Bisinotto, L. F. Greco, E. S. Ribeiro, F. Maunsell, K. Galvão, and J. E. P. Santos. 2012. Evaluation of peripartal calcemic status, energetic profile, and neutrophil function in dairy cows at low or high risk of developing uterine disease. J. Dairy Sci. 95:7158-7172. https://doi.org/10 $.3168 /$ jds.2012-5812.

Martinez, N., L. D. P. Sinedino, R. S. Bisinotto, R. Daetz, C. Lopera, C. A. Risco, K. N. Galvão, W. W. Thatcher, and J. E. P. Santos. 2016. Effect of oral calcium supplementation on mineral and acidbase status, energy metabolites, and health of postpartum dairy cows. J. Dairy Sci. 99:8397-8416. https://doi.org/10.3168/jds.2015 $-10527$. 
Martinez, N., L. D. P. Sinedino, R. S. Bisinotto, E. S. Ribeiro, G. C. Gomes, F. S. Lima, L. F. Greco, C. A. Risco, K. N. Galvão, D. Taylor-Rodriguez, J. P. Driver, W. W. Thatcher, and J. E. P. Santos. 2014. Effect of induced subclinical hypocalcemia on physiological responses and neutrophil function in dairy cows. J. Dairy Sci. 97:874-887. https://doi.org/10.3168/jds.2013-7408.

McDougall, S., R. Macaulay, and C. Compton. 2007. Association between endometritis diagnosis using a novel intravaginal device and reproductive performance in dairy cattle. Anim. Reprod. Sci. 99:9 23. https://doi.org/10.1016/j.anireprosci.2006.03.017.

Melendez, P., A. Donovan, C. A. Risco, M. B. Hall, R. Littell, and J. Goff. 2002. Metabolic response of transition Holstein cows fed anionic salts and supplemented at calving with calcium and energy. J. Dairy Sci. 85:1085-1092. https://doi.org/10.3168/jds.S0022 -0302(02)74169-6.

Melton, L. A., M. L. Tracy, and G. Möller. 1990. Screening trace elements and electrolytes in serum by inductively-coupled plasma emission spectrometry. Clin. Chem. 36:247-250.

Milliken, G. A., and D. E. Johnson. 2001. Special Applications of Analysis of Covariance. Pages 533-590 in Analysis of Messy Data, Volume III: Analysis of Covariance. CRC Press, Boca Raton, FL.

Miltenburg, C. L., T. F. Duffield, D. Bienzle, E. L. Scholtz, and S. J. LeBlanc. 2016. Randomized clinical trial of a calcium supplement for improvement of health in dairy cows in early lactation. J. Dairy Sci. 99:6550-6562. https://doi.org/10.3168/jds.2016-10961.

Moore, S. J., M. J. VandeHaar, B. K. Sharma, T. E. Pilbeam, D. K. Beede, H. F. Bucholtz, J. S. Liesman, R. L. Horst, and J. P. Goff. 2000. Effects of dietary cation-anion difference on calcium and energy metabolism in peripartum cows. J. Dairy Sci. 83:2095-2104. https://doi.org/10.3168/jds.S0022-0302(00)75091-0.

Morris, J. D., J. M. Fernandez, A. M. Chapa, L. R. Gentry, K. E. Thorn, and T. M. Weick. 2002. Effects of sample handling, processing, storage, and hemolysis on measurements of key energy metabolites in ovine blood. Small Rumin. Res. 43:157-166. https:// doi.org/10.1016/S0921-4488(01)00266-8.

Oetzel, G. R., and B. E. Miller. 2012. Effect of oral calcium bolus supplementation on early-lactation health and milk yield in commercial dairy herds. J. Dairy Sci. 95:7051-7065. https://doi.org/ 10.3168/jds.2012-5510.

Ospina, P. A., D. V. Nydam, T. Stokol, and T. R. Overton. 2010. Evaluation of nonesterified fatty acids and $\beta$-hydroxybutyrate in transition dairy cattle in the northeastern United States: Critical thresholds for prediction of clinical diseases. J. Dairy Sci. 93:546554. https://doi.org/10.3168/jds.2009-2277.

Reinhardt, T. A., J. D. Lippolis, B. J. McCluskey, J. P. Goff, and R. L. Horst. 2011. Prevalence of subclinical hypocalcemia in dairy herds. Vet. J. 188:122-124. https://doi.org/10.1016/j.tvjl.2010.03.025.

Ribeiro, E. S., F. S. Lima, L. F. Greco, R. S. Bisinotto, A. P. A. Monteiro, M. Favoreto, H. Ayres, R. S. Marsola, N. Martinez, W. W. Thatcher, and J. E. P. Santos. 2013. Prevalence of periparturient diseases and impacts on fertility of seasonally calving grazing dairy cows supplemented with concentrates. J. Dairy Sci. 96:5682-5697. https://doi.org/10.3168/jds.2012-6335.

Roche, J. R., and D. P. Berry. 2006. Periparturient climatic, animal, and management factors influencing the incidence of milk fever in grazing systems. J. Dairy Sci. 89:2775-2783. https://doi.org/10 .3168/jds.S0022-0302(06)72354-2.

Rorsman, P., and G. Trube. 1986. Calcium and delayed potassium currents in mouse pancreatic beta-cells under voltage-clamp conditions. J. Physiol. 374:531.

Rosol, T. J., D. J. Chew, L. A. Nagode, and C. C. Capen. 1995. Pathophysiology of calcium metabolism. Vet. Clin. Pathol. 24:49-63.

Russell, K. E., and A. J. Roussel. 2007. Evaluation of the ruminant serum chemistry profile. Vet. Clin. North Am. Food Anim. Pract. 23:403-426. https://doi.org/10.1016/j.cvfa.2007.07.003.

Sampson, J. D., J. N. Spain, C. Jones, and L. Carstensen. 2009. Effects of calcium chloride and calcium sulfate in an oral bolus given as a supplement to postpartum dairy cows. Vet. Ther. 10:131-139.

Sprecher, D. J., D. E. Hostetler, and J. B. Kaneene. 1997. A lameness scoring system that uses posture and gait to predict dairy cattle reproductive performance. Theriogenology 47:1179-1187. https:// doi.org/10.1016/S0093-691X(97)00098-8.

USDA National Animal Health Monitoring System (NAHMS). 2014 Dairy cattle management practices in the United States. http:// www.aphis.usda.gov/animal_health/nahms/dairy/downloads/ dairy14/Dairy14_dr_PartI.pdf.

Williams, E. J., D. P. Fischer, D. U. Pfeiffer, G. C. W. England, D. E. Noakes, H. Dobson, and I. M. Sheldon. 2005. Clinical evaluation of postpartum vaginal mucus reflects uterine bacterial infection and the immune response in cattle. Theriogenology 63:102-117. https://doi.org/10.1016/j.theriogenology.2004.03.017. 